Iryna Sotnyk,

D.Sc., Professor, Sumy State University, Ukraine

Kostiantyn Zavrazhnyi,

Sumy State University, Ukraine

Volodymyr Kasianenko,

D.Sc., Sumy State University, Ukraine

Hynek Roubík,

Ph.D., Czech University of Life Sciences Prague, Czechia

Oleksandr Sidorov,

INGENUM, Spain

\title{
INVESTMENT MANAGEMENT OF BUSINESS DIGITAL INNOVATIONS
}

Abstract. This paper considers the issue of investment management of digital innovations in modern business. The main purpose of the research is the development of approaches to the investment management of the innovative digitalisation processes of the enterprises and justification of the economic efficiency of investment projects on innovative information technologies use in the context of their relationship with existing information solutions for enterprise management. The relevance of the research is the necessity to change the methods of doing and managing the modern business, taking into account the achievements of the Third and Fourth Industrial Revolutions, which form innovative business philosophy based on informatisation and digitalisation of manufacturing and delivery processes. The implementation of innovative digital technology in business processes requires significant costs and it raises the issue on their minimization. Systematization of literary sources and approaches for the investment management of industrial digitalisation indicates the absence of complex solutions for this problem. In this regard, based on a comparative analysis, the authors have revealed the features of business development in the conditions of the Fourth Industrial Revolution and justified the need for modern information systems integration for enterprise management on the platform of business processes digitalisation. In order to create the road map of business digital innovations, it is suggested that the Theory of Constraints should be used to determine which of the operating information systems of the enterprise (Business intelligence - Bl; Enterprise Resource Planning - ERP; Manufacturing Execution System MES; Industrial Internet of Things - IloT) is to begin the digital transformation with. The stages of the project development for the digital transformation of an enterprise are designed based on the structural approach. The economic justification for the selection of alternative digitalisation projects is based on an assessment of the labour costs for implementing two variants of digital innovation of a business entity: a complex automation project with upfront modelling and an integration automation project with the gradual implementation of a new information system. The assessment results have shown the economic benefits of implementing the integration project as it provides 1.58 times fewer labour costs and can be realized by use of universal package solutions such as Business Automaton Software (BAS). The analysis of the results of the implemented business digitalisation projects in Ukraine and the world as well as the potential of planned ones has allowed generalising the effects of their implementation and confirmed the need for further development of the mechanisms for the investment management of business digital innovations.

Keywords: automation, business, digitalisation, efficiency, greening, ERP, information technology, innovation, investment management, project.

Introduction. The implementation of the achievements of the Third (Industry 3.0) and Fourth (Industry 4.0) Industrial Revolutions into the economic practice transforms economic and environmental systems and makes important changes in the methods of doing and managing the modern business. Revolutionary innovations affect businesses due to the transformation of consumer expectations, product development, joint innovation, and new organisational forms of management (Schwab, 2016). Altogether, they are changing the foundations of doing business, demanding the formation of new business philosophy based on informatisation and digitalisation of the manufacturing and delivery processes. Besides, such changes

Cite as: Sotnyk, I., Zavrazhnyi, K., Kasianenko, V., Roubík H. \& Sidorov O. (2020). Investment Management of Business Digital Innovations. Marketing and Management of Innovations, 1, 95-109. http://doi.org/10.21272/mmi.2020.1-07 
lead to an increase in manufacturing efficiency and have a positive effect on greening and decarbonising the national economies. The implementation of information technology (IT) into investment projects for business digital innovations is playing a key role in this regard. At the same time, while implementing digital solutions into the activities of business entities, there often occur issues on the investment management of the manufacturing systems transition to new technological platforms. The issues on ensuring minimum costs for this transition are of great relevance since such investment projects tend to be costly.

Literature Review. Nowadays, many foreign scientists (such as M. Blix (Blix, 2015), Ch. Gupta (Gupta, 2018), L. Hounshell (Hounshell, 2018), D. Horvat, A. Jäger, H. Kroll (Kroll et al., 2018), I. Barandiaran, J. Posada, C. Toro (Posada et al., 2015), F. Bergeron, L. Raymond (Raymond et al., 2009), M. Brettel, N. Friederichsen, M. Keller (Brettel et al., 2014), K. Schwab (Schwab, 2016 et al.) and domestic researchers (such as V. V. Apal'kova (Apal'kova, 2015), G. T. Karcheva (Karcheva et al., 2017), S. V. Kolyadenko (Kolyadenko, 2016), O. P. Holoborod'ko, N. M. Kraus (Kraus et al., 2018), V. V. Pilinsky (Veretyuk and Pilinsky, 2016), O. V. Prokopenko (Prokopenko et al., 2019), M. V. Rudenko (Rudenko, 2018), I. V. Tokmakova (Tokmakova et al., 2018) investigate the business digital innovations. There have been already determined theoretical and conceptual foundations of the digitalisation development, for example by (Kroll et al., 2018; Posada et al., 2015; Brettel et al., 2014; Apal'kova, 2015; Ошибка! Закладка не определена.; Kraus et al., 2018; Melnyk et al., 2017; Rudenko, 2018; Tokmakova et al., 2018). Other authors studied the factors that stimulate and impede its spreading (Blix, 2015; Hounshell, 2018; Kroll et al., 2018; Raymond et al., 2009; Karcheva et al., 2017), estimated positive and negative consequences of its impact on the spheres of economic activity and territories (Schwab, 2016; Blix, 2015; Kroll et al., 2018; Brettel et al., 2014; Karcheva et al., 2017; Ошибка! Закладка не определена.), investigated the disclosure level of Corporate Social and Environmental Responsibility information on Ukrainian companies' websites and its impact on the competitiveness (Hakobuan et al., 2019), as well as made the forecasts for the digital economy deployment (Blix, 2015; Veretyuk and Pilinsky, 2016).

For example, Kolyadenko (2016) studied the conceptual approaches to the definition of «digital economy», preconditions of its emerging and development in the world. Rudenko (2018) considers the essence and principles of the economies' digitalisation as well as substantiates the advantages of the business digitalisation implementation.

Melnyk et al. (2017) argue that today any system should involve the provision of a single ('digital') basis for fixing and transmitting information (for the implementation of communication between people, a man with a machine and a machine with a machine). Goncharenko and Sotnyk (2015) point out at an important role of informatisation and digitalisation in the transformation processes of a modern enterprise. In this context, the authors consider the implementation of dematerialisation mechanisms in production and consumption sectors that help to reduce both material flows and eco-destructive impact at different hierarchical levels.

Kroll et al. (2018) differentiate between effects resulting from advanced, yet still traditional automatisation and those resulting from a more comprehensive, systemically transformation by the digitalisation of the production process.

Blix (2015) survey evidence of the effects of digitalisation across many different dimensions of society. He concludes that it is expedient to study both past experience of technological change and the effects of long-run trends, such as ageing populations and urbanization within the context of digitalisation.

Sotnyk et al. (2013), Bilan et al. (2019), Ibragimov et al. (2019, 2019a) and Rubanov et al. (2019) investigate the ecological and economic effects of IT for the national economies development in the short and long-run periods and propose measures to reduce negative consequences of IT implementation as well as to enhance the positive influence of these technologies on business and public sectors.

Brettel et al. (2014) reveal reasons for the adaption and refusal of Industry 4.0 practices from a managerial point of view. 
Apal'kova (2015) studies five dimensions of the digital entrepreneurship programme declared in the strategic documents of the European Commission and member states as well as analyses fundamental differences and specific elements of the digital economy development in the EU and Ukraine. On this basis, the researcher identifies the key areas for transformation of the regulatory environment in order to achieve the maximum efficiency and growth of the digital economy.

Using the DESI (Digital Economy and Society Index) methodology, Veretyuk and Pilinsky (2016) formed a model of digital economy structure and estimated the technological gap between Ukraine and European countries with the help of the cluster analysis. On this basis, the authors identified the key measures to overcome the technological gap.

The world's leading corporations attach great importance to the implementation of IT into the processes of industrial manufacturing and distribution systems since such investments lead to a significant increase in companies' competitive advantages and customer loyalty in the market environment that is changing rapidly. At the same time, the digital innovations in business often face the problem of aligning existing enterprises' information systems with new generations of digital technologies, i.e. integration of new methods and optimization of existing management systems. In this case, the main requirement is to ensure both the interaction of ITs and a gradual transition to a new technology platform as well as to provide the maximal use of the existing systems for manufacturing purposes if necessary, along with minimising their costs. As of today, the issues of investment management for industrial digital innovations are studied partially and require further research.

Therefore, the aim of the research is to develop the approaches to the investment management of the innovative digitalisation processes of the enterprises and to justify the economic efficiency (based on labour approach) of the innovative investment projects for IT use in the context of the relationship with existing information solutions on enterprise management.

Methodology and research methods. While carrying out the research, we used the comparative analysis for determining the specific features of business development in the conditions of the Third and Fourth Industrial Revolutions. It enabled justifying the need for integration of modern enterprise management information systems on the business processes digitalisation platform. The theory of constraints was applied for developing a road map of business digital transformation since unlike other methods, it provided a reproducible cycle of digitalisation options optimization for the enterprise. In addition, based on the current and future limitations of the company's integrated information system, which might arise during the implementation of each digitisation project, the theory of constraints helped to substantiate the feasibility of options' choosing.

We considered the following two mutually exclusive research hypotheses for determining the optimal option of the enterprise digitalisation project:

HO. Minimal changes in the enterprise information systems, which are based on the parallel implementation of new IT and their coordination with ones existing at the enterprise, i.e. complex automation projects with up-front modelling, provide the minimum total time and cost for their implementation for the companies.

H1. Enterprise automation projects, which are based on IT integration and the gradual implementation of a new information system, provide minimal total costs of time and money for firms due to minimization of the number of human-involving operations and their replacement with machine work.

The use of the structural approach made it possible to form the project development stages for enterprise digital transformation. The application of labour method for calculating the economic efficiency of alternative projects for the digital transformation of business entities helped to compare the projects' effectiveness and eliminate the possibility of errors related to discounting economic costs. We used a hypothetical enterprise's data formed on the basis of averaged data of Ukrainian companies of different types of economic activity, which had implemented projects on business automation and digitisation in the 
last 3 years. The analysis and synthesis method provided summarizing the effects of the projects' implementation for business digitalisation.

Results. Today we witness a clear evidence that the technologies, which drive the Fourth Industrial Revolution, have a serious impact on business. In particular, there is the implementation of new manufacturing systems that create completely new ways to meet existing consumer needs. Nowadays, business technologies are connecting people and spreading via the devices, data and systems that form our digital world by the Internet. Industrial Internet of Things (IloT) is the type of infrastructure that allows businesses to cope with this evolution (Gartner, 2019).

Any product can be customized using IloT. This means that it is able to meet the needs of a particular consumer, for example, as it is provided by the automotive industry now, where the consumer can choose the colour of the car, its interior trim, etc. However, instead of the rising price of products due to their individualisation, there is a reduction in the manufacturing and marketing costs for goods and services owing to the success of Industry 4.0. This is due to the high level of interaction between automated production systems, which reduces manufacturing costs not only through the rational use of material and energy resources but also labour force. The consequence of such transformations is that the factor of affordable human resources is gradually losing its former significance for large enterprises (Deutsche Welle, 2019). This is confirmed by the trends of returning the manufacturing of the world's leading industrial corporations from Asia to Europe in an effort to ensure the high quality of their products. At the same time, the revival of such enterprises is accompanied by hiring far less number of workers than before. A striking example is the factory producing irons of brand Rowenta owned by the Groupe SEB (France) and located in Erbach city. In 2005, the enterprise administration, which found itself in a crisis, announced that it did not see an alternative to move part of the manufacturing (the simplest and cheapest models) to China, and dismissed almost $40 \%$ of the workers ( 215 jobs). In 2018 , the enterprise returned a significant part of manufacturing to Erbach city and hired only 15 new employees. The enterprise did not need more employees as during the decade and a half industrial robots «learnt» to do devices that were earlier done by a man (Again, 2019).

An integral part of the Fourth Industrial Revolution is the digitalisation processes that are determined by Gartner (2019) as the use of digital technologies to change business models and provide new opportunities for gaining profit and value creation. This is an evolutionary process that was observed in various industries during some period and coincides with Industry 4.0 (Hounshell, 2018). The development of digitalisation is accompanied by digital transformation, i.e. the integration of digital technologies in all spheres of business activity that requires significant changes in technology, culture, operations and the principles of creating new products and services. Therefore, enterprises should completely transform operation processes and models for the most efficient use of new technologies and their fast implementation in business practice.

Digital transformation requires a shift in focus to production periphery and an increase in flexibility for data processing centres that should support that periphery. This process also means the gradual abandonment of obsolete technologies, the maintenance of which can be expensive for enterprises, as well as a change in culture, which should now support the acceleration of processes provided by digital transformation (Hewlett Packard, 2019). At the same time, the entrepreneurs and enterprises' owners should not think for three to five years ahead, but change their business for generations to come: implement digital systems, leading software and smart equipment in order to be able to design and test new products in a digital environment (Zielinski, 2019).

Unlike Industry 3.0, which was aimed at the automation of manufacturing, Industry 4.0 is aimed precisely at the digital transformation of business processes (Schwab, 2016). In this context, the Chief digital officer (CDO) starts to play a key role in changes at enterprises. His main responsibilities are to transform traditional operations into digital processes in order to eliminate the human role in decision- 
making as much as possible. $\mathrm{CDO}$ are aimed at creating new entrepreneurial opportunities, income flows and customer service through the implementation of digital technologies. For example, PwC Strategy\& consulting practice indicates that $19 \%$ of 2500 world's largest public enterprises had CDO in 2017. In Europe, this figure had reached $38 \%$ (Samuels, 2018). One of the key aspects of achieving a goal of CDO is a necessity to build the interconnection of decisions of Business intelligence (BI), Enterprise Resource Planning (ERP), Manufacturing Execution System (MES) and IloT at an enterprise during the business digital transformation. The characteristics of these systems within the enterprise are given in Table 1. All of these systems help to increase manufacturing efficiency, but their coordination among themselves is often a difficult task for practical implementation.

Table 1. Characteristics of modern information systems for enterprise management

\begin{tabular}{|c|c|}
\hline $\begin{array}{l}\text { Information } \\
\text { system }\end{array}$ & Characteristics \\
\hline $\begin{array}{c}\text { Business } \\
\text { intelligence } \\
\text { (BI) }\end{array}$ & $\begin{array}{l}\text { Computer methods and tools for enterprises that provide the conversion of transactional } \\
\text { business information to the format that is suitable for business analysis, as well as tools for } \\
\text { work with conversed information. The tasks of } \mathrm{BI} \text { are as follows: 1) data clearing and } \\
\text { consolidation, conversion of data into a format that is convenient for analysis; 2) interpretation } \\
\text { of a large amount of data and highlighting key factors affecting efficiency; 3) modelling the } \\
\text { result of various variants of actions and tracking the results of decision-making. The main } \\
\text { purpose of } \mathrm{BI} \text { is business decision-making. }\end{array}$ \\
\hline $\begin{array}{l}\text { Enterprise } \\
\text { Resource } \\
\text { Planning } \\
\text { (ERP) }\end{array}$ & $\begin{array}{l}\text { An organisational strategy for the integration of manufacturing and operations, human } \\
\text { resources management, financial management and assets management that is aimed at } \\
\text { continuous balancing and optimization of the enterprise resources using a specialized } \\
\text { integrated application software package, which provides a common model of data and } \\
\text { process for all areas of the enterprise activity. A software package that implements an ERP } \\
\text { strategy is usually a set of modules, the number of which may vary depending on the size } \\
\text { and characteristics of enterprises where the ERP system is being implemented. The standard } \\
\text { set of modules that can be implemented stage by stage is as follows: finance and accounting, } \\
\text { personnel management, warehouse, sales, customer relationship management (CRM), } \\
\text { procurement, supply chain management (SCM), manufacturing. }\end{array}$ \\
\hline $\begin{array}{l}\text { Manufacturing } \\
\text { Execution } \\
\text { System (MES) }\end{array}$ & $\begin{array}{l}\text { A specialised system designed to solve the problems of synchronization, coordination, } \\
\text { analysis and optimization of manufacturing the enterprise product. } \\
\text { MES functions include: RAS (resource allocation and status); ODS (operations/detail } \\
\text { scheduling); DPU (dispatching production units); DOC (document control); DCA (data } \\
\text { collection/ acquisition); LM (labour management); QM (quality management); PM (process } \\
\text { management); MM (maintenance management); PTG (product tracking and genealogy); PA } \\
\text { (performance analysis). }\end{array}$ \\
\hline $\begin{array}{l}\text { Industrial } \\
\text { Internet of } \\
\text { Things (IloT) }\end{array}$ & $\begin{array}{l}\text { A system of integrated computer networks and industrial (manufacturing) facilities connected } \\
\text { to them with built-in sensors and software for data collection and exchange, with the function } \\
\text { of remote control and management in an automated mode without human involvement. At the } \\
\text { first stage of IloT implementation, the sensors, actuators, controllers, and human-machine } \\
\text { interfaces are installed on industrial equipment, which makes it possible to collect information. } \\
\text { This allows management to receive objective and accurate data on the manufacturing. The } \\
\text { processed data are spread to all departments of the enterprise for establishing interaction } \\
\text { between employees of various departments and making informed decisions. The information } \\
\text { received can be used to prevent unplanned downtime, equipment breakdowns, reduction of } \\
\text { unscheduled maintenance and failures in supply chain management. All of this will allow the } \\
\text { enterprise to operate more efficiently. At the next stages of IloT implementation, the advanced } \\
\text { analytical platforms are used. They are designed to collect, store and analyse data on } \\
\text { technological processes and events and operate in real-time. }\end{array}$ \\
\hline
\end{tabular}

Sources: systematised by the authors based on (IT-Enterprise, 2019) 
As a rule, enterprise executives focus on the cost reduction through their initiatives in the field of ERP. The increase in productivity, reduction of IT maintenance costs and optimization of business processes are often the main reasons for implementing new ERP systems. At the same time, $\mathrm{BI}$, reports, analytical and information dashboards can help realize most of the advantages of ERP system. In particular, $\mathrm{BI}$ provides the formation of effective measures for managing organizational changes as in the case of any implementation of corporate software or digital transformation (Panorama, 2016).

MES and ERP systems of manufacturers are often developed by different software vendors and speak different languages, so the integration of these systems can become a problem. On the other hand, due to the increase in the amount of data used to improve manufacture processes, there is observed the increase in cross-communication and interaction between system components that in turn makes it easier to find ways for their coordination and interaction (Lavi, 2017).

By integrating ERP and manufacturing data for more accurate demand forecasts, enterprises can reduce inventories by avoiding overproduction. With the implementation of IloT, the manufacture is revolutionizing by using intelligent connected devices at factories. This creates more opportunities to finetune the operations with better integration of data and processes, business intelligence systems, MES and ERP of enterprises.

According to the estimates of experts, IloT plays a key role in the integration of information systems of enterprises. For example, with regard to the results of survey conducted by Accenture, $84 \%$ of more than 1400 global business leaders stated that they could create new income flows by implementing IloT solutions. The installed base of manufacturing IloT devices is expected to increase from 237 million in 2015 to 923 million in 2020 (Lavi, 2017).

Theory of Constraints (TOC) can become useful and practical tool for integration of BI, MES, ERP and IloT systems at enterprises in order to develop the road maps of digital transformation. TOC is a methodology for determining the most important limiting factor (i.e. limitation or bottleneck) that hampers the achievement of a specific goal and further systematic alleviation of this limitation until it ceases to be a limiting factor. This theory uses a scientific approach to solving manufacture problems and provides that each complex system (including manufacturing processes) consists of many related actions. One of these actions acts as a limitation of the entire system, i.e., it is «the weakest link in the chain» (Theory, 2019). Thus, using this scientific approach, it is possible to justify the selection of one of the above mention information system to be the first one in the process of digital transformation.

For example, BI can provide information in a form of Key Performance Indicators (KPI) analysis and Balanced Score Card (BSC) mapping. This information will help executives to manage the transformation process. At the same time, the transition from an outdated ERP system to a new, innovative one will make it possible to create a modern tool for the manufacture development due to the enterprise transformation and ERP integration with existing information systems of business entity. The implementation of MES together with IloT and the consistent integration of these processes into ERP will ensure the transfer of information flows in both directions. In particular, a detailed manufacturing plan will be transferred from the ERP level to MES level, and the fast response regarding the execution - from the MES level to the ERP level. The inclusion of IloT in this contour will help to carry out the manufacturing processes of the lower level using modern interaction technologies without human involvement (Gupta, 2018). In view of these opportunities for the information systems integration, the necessity for the development of a digital transformation project of the enterprise arises, which, in our opinion, should cover few stages.

At the first stage, it is advisable to determine and analyse the specific features of the information systems operating at the enterprise and the degree of their interaction. If business entity has many disparate information systems, the attempt to coordinate their actions will cause the occurrence of complex integration processes. The support of these processes will require a large amount of resources. Therefore, it is a futile decision to leave everything as it is, and just add new interconnections and thereby complicate 
the managerial decisions transmitting. In this regard, at the second stage, it is necessary to carry out a comprehensive analysis of the role of a man in points of decision-making in the enterprise management system. On this basis, it is advisable to compare the capabilities of various modern ERP systems, their relationship with $\mathrm{BI}, \mathrm{MES}$ and IloT, as well as assess the prospects of their integration with the electronic document management system. This will allow to identify the manufacturing areas where human resources can be replaced by machine ones that will significantly increase the manufacturing efficiency. The results of this analysis will ensure the optimal use of IT in the process of digital transformation. At the third stage, based on the results of the previous two stages, an optimization plan should be developed. Its purpose is the digital transformation of business processes into a single enterprise management system with involving advanced IT. It will be the beginning of the process of the enterprise complex digital transformation. The result of this stage is the development of a package of information solutions, the implementation of which will ensure the achievement of the goals of digitalisation of manufacturing.

The implementation of the suggested organizational approach to the development of the project for enterprise digital transformation makes it possible to integrate innovative IT with ones existing at the enterprise. In addition, it allows minimizing the number of operations, which involve humans, and replace them with machine work. At the same time, many enterprises choose the parallel implementation of new IT and their coordination with ones existing at the enterprise, i.e. complex automation projects with upfront modelling. This is due to the effort to change the existing information systems as little as possible in order to save time and money on employee training. In this regard, we will assess the economic efficiency of these two variants for digital transformation of a business entity based on the labour approach (hypotheses $\mathrm{HO}$ and $\mathrm{H} 1$ ). In Table 2 we present a scheme of a complex project for the automation of an industrial enterprise using ERP system that provides the coordination of existing information processes with new IT (with regard to hypothesis $\mathrm{H} 0$ ). According to Table 2, the implementation of such a project lasts from 8 to 18 months.

Table 2. Scheme of a complex project for the automation of an industrial enterprise with up-front modelling

\begin{tabular}{|c|c|c|c|c|}
\hline \multicolumn{5}{|c|}{ mong } \\
\hline No. & Stage & Result & Duration & $\begin{array}{l}\text { Human } \\
\text { resources }\end{array}$ \\
\hline \multicolumn{5}{|c|}{ Beginning of a project } \\
\hline 1 & $\begin{array}{c}\text { Approval and purchase of a software } \\
\text { product }\end{array}$ & $\begin{array}{l}\text { Ownership rights for software } \\
\text { are purchased }\end{array}$ & $\begin{array}{c}1-2 \\
\text { weeks }\end{array}$ & $\begin{array}{l}\text { Project monitor } \\
\text { Project } \\
\text { manager }\end{array}$ \\
\hline 2 & $\begin{array}{l}\text { Installation and initial setup of a } \\
\text { software product }\end{array}$ & $\begin{array}{l}\text { System is configured for up- } \\
\text { front modelling }\end{array}$ & $\begin{array}{c}1-2 \\
\text { weeks }\end{array}$ & $\begin{array}{l}\text { System } \\
\text { administrator } \\
\text { Consultant } \\
\text { Key users }\end{array}$ \\
\hline 3 & $\begin{array}{l}\text { Express survey for collecting data for } \\
\text { the modelling }\end{array}$ & Express Survey Report & $\begin{array}{c}2-4 \\
\text { weeks }\end{array}$ & $\begin{array}{l}\text { Consultant } \\
\text { Key users }\end{array}$ \\
\hline \multirow[t]{2}{*}{4} & $\begin{array}{l}\text { Entering reference data (RD) and } \\
\text { adding residuals for the modelling }\end{array}$ & The up-front modelling started & \multirow{2}{*}{$\begin{array}{c}1-3 \\
\text { months }\end{array}$} & \multirow{2}{*}{$\begin{array}{c}\text { Project } \\
\text { manager } \\
\text { Consultant } \\
\text { Developer } \\
\text { Key users }\end{array}$} \\
\hline & $\begin{array}{l}\text { Modelling based on Express Survey } \\
\text { Report }\end{array}$ & New system model & & \\
\hline \multirow[t]{2}{*}{5} & $\begin{array}{l}\text { Identification of specific features of } \\
\text { accounting and the implementation of } \\
\text { necessary reworks }\end{array}$ & $\begin{array}{l}\text { Formation of automation project } \\
\text { constraints }\end{array}$ & \multirow{2}{*}{$\begin{array}{c}2-4 \\
\text { months }\end{array}$} & \multirow{2}{*}{$\begin{array}{c}\text { Project } \\
\text { manager } \\
\text { Consultant } \\
\text { Developer } \\
\text { Users } \\
\end{array}$} \\
\hline & $\begin{array}{l}\text { Preparation of user instructions and } \\
\text { initial training of employees }\end{array}$ & $\begin{array}{l}\text { The system is ready for } \\
\text { implementation }\end{array}$ & & \\
\hline
\end{tabular}


Continued Table 2

\begin{tabular}{|c|c|c|c|c|}
\hline \multirow[t]{2}{*}{6} & $\begin{array}{l}\text { Entering RD and adding residuals for } \\
\text { the implementation }\end{array}$ & $\begin{array}{l}\text { The system is ready for } \\
\text { operational testing }\end{array}$ & \multirow{2}{*}{$\begin{array}{c}1-3 \\
\text { months }\end{array}$} & \multirow{2}{*}{$\begin{array}{l}\text { Project monitor } \\
\text { Project manager } \\
\text { Consultant } \\
\text { Developer } \\
\text { Users }\end{array}$} \\
\hline & Operational testing & $\begin{array}{l}\text { Monitoring the readiness of the } \\
\text { system for industrial operation }\end{array}$ & & \\
\hline \multirow[t]{2}{*}{7} & \multicolumn{2}{|c|}{ Industrial operation } & \multirow[b]{2}{*}{$\begin{array}{c}3-6 \\
\text { months }\end{array}$} & Project monitor \\
\hline & \multicolumn{2}{|c|}{ System stabilization (working at functional comments) } & & $\begin{array}{c}\text { System } \\
\text { administrator } \\
\text { Consultant } \\
\text { Developer } \\
\text { Users }\end{array}$ \\
\hline \multicolumn{5}{|c|}{ Support } \\
\hline
\end{tabular}

Sources: developed by the authors

The project human resources include its monitor and manager, automation specialists and end users. We estimate the labour costs for the project according to the participation coefficients of performers and users at each stage and with the implementation deadline of 1.5 years (Table 3 ).

Table 3. Calculation of labour costs for the development and operating of a complex project for the enterprise automation with up-front modelling

\begin{tabular}{|c|c|c|c|}
\hline Type of human resources & $\begin{array}{c}\text { Participation } \\
\text { coefficient }\end{array}$ & Stages of project implementation & $\begin{array}{l}\text { Calculation of } \\
\text { labour costs }\end{array}$ \\
\hline Project monitor & 0.1 & $\begin{array}{l}\text { Stage } 1=2 \text { weeks } \\
\text { Stage } 6=3 \text { months } \\
\text { Stage } 7=6 \text { months }\end{array}$ & $\begin{array}{l}(0.5+9) * 160 * 0.1 \\
=152 \text { hours }\end{array}$ \\
\hline Project manager & 0.2 & $\begin{array}{l}\text { Stage } 1=2 \text { weeks } \\
\text { Stage } 4=3 \text { months } \\
\text { Stage } 5=4 \text { months } \\
\text { Stage } 6=3 \text { months } \\
\text { Stage } 7=6 \text { months }\end{array}$ & $\begin{array}{l}(0.5+16) * 160 * \\
0.2=528 \text { hours }\end{array}$ \\
\hline System Administrator & 0.05 & $\begin{array}{l}\text { Stage } 2=2 \text { weeks } \\
\text { Stage } 7=6 \text { months }\end{array}$ & $\begin{array}{l}(0.5+6) * 160 * \\
0.05=52 \text { hours }\end{array}$ \\
\hline Consultant & 1 & $\begin{array}{l}\text { Stage } 2=2 \text { weeks } \\
\text { Stage } 3=4 \text { weeks } \\
\text { Stage } 4=3 \text { months } \\
\text { Stage } 5=4 \text { months } \\
\text { Stage } 6=3 \text { months } \\
\text { Stage } 7=6 \text { months }\end{array}$ & $\begin{array}{l}(1.5+16) * 160 * 1 \\
=2800 \text { hours }\end{array}$ \\
\hline Developer & 0.5 & $\begin{array}{l}\text { Stage } 4=3 \text { months } \\
\text { Stage } 5=4 \text { months } \\
\text { Stage } 6=3 \text { months } \\
\text { Stage } 7=6 \text { months }\end{array}$ & $\begin{array}{c}16 * 160 * 0.5= \\
1280 \text { hours }\end{array}$ \\
\hline Key users & 0.5 & $\begin{array}{l}\text { Stage } 2=2 \text { weeks } \\
\text { Stage } 3=4 \text { weeks } \\
\text { Stage } 4=3 \text { months }\end{array}$ & $\begin{array}{c}4.5 * 160 * 0.5=360 \\
\text { hours }\end{array}$ \\
\hline Users & 5 & $\begin{array}{l}\text { Stage } 5=4 \text { months } \\
\text { Stage } 6=3 \text { months } \\
\text { Stage } 7=6 \text { months }\end{array}$ & $\begin{array}{c}13 * 160 * 5=10400 \\
\text { hours }\end{array}$ \\
\hline \multicolumn{3}{|c|}{ Total } & 15572 hours \\
\hline
\end{tabular}

Sources: developed by the authors 
To make calculation easier, we consider working week to be 40 hours, 1 month is conditionally equal to 4 weeks or 160 hours, the participation coefficient varies from 0 to 1 ( 1 indicates full participation) and is taken as a single value for a particular type of human resource.

Thus, a complex project for the enterprise automation with up-front modelling requires 15572 hours for its implementation and operating. 30.9\% (4812 hours) of the labour costs is spent on the work of the project executors, and the rest $69.1 \%$ (10760 hours) on its different users.

Table 4 contains characteristics of the project for the automation of the same enterprise based on IT integration and the gradual implementation of a new information system (with regard to hypothesis $\mathrm{H} 1$ ).

Table 4. Scheme of an integration project for the automation of the industrial enterprise with gradual implementation of a new system

\begin{tabular}{|c|c|c|c|c|}
\hline & \\
\hline No. & Stage & Result & Duration & Human resources \\
\hline \multicolumn{5}{|c|}{ Beginning of a project } \\
\hline 1 & $\begin{array}{c}\text { Approval and purchase of a } \\
\text { software product }\end{array}$ & $\begin{array}{c}\text { Ownership rights for software } \\
\text { are purchased }\end{array}$ & $1-2$ weeks & $\begin{array}{l}\text { Project monitor } \\
\text { Project manager }\end{array}$ \\
\hline 2 & $\begin{array}{l}\text { Installation and initial setup } \\
\text { of a software product }\end{array}$ & $\begin{array}{l}\text { The system is configured for } \\
\text { integration }\end{array}$ & $1-2$ weeks & $\begin{array}{l}\text { System administrator } \\
\text { Consultant } \\
\text { Key users }\end{array}$ \\
\hline 3 & $\begin{array}{l}\text { Express survey for getting } \\
\text { composition of the } \\
\text { integration objects }\end{array}$ & $\begin{array}{l}\text { Requirement list for the } \\
\text { integration task }\end{array}$ & $2-4$ weeks & $\begin{array}{l}\text { Consultant } \\
\text { Developer } \\
\text { Key users }\end{array}$ \\
\hline 4 & $\begin{array}{l}\text { Integration of systems in } \\
\text { accordance with the } \\
\text { requirement list }\end{array}$ & $\begin{array}{l}\text { Information is transferred to } \\
\text { the new system }\end{array}$ & $1-3$ months & $\begin{array}{l}\text { Project manager } \\
\text { Consultant } \\
\text { Developer } \\
\text { Key users }\end{array}$ \\
\hline \multirow[t]{2}{*}{5} & $\begin{array}{l}\text { Identification of specific } \\
\text { features of accounting and } \\
\text { the implementation of } \\
\text { necessary reworks }\end{array}$ & $\begin{array}{c}\text { Formation of automation } \\
\text { project constraints }\end{array}$ & \multirow[t]{2}{*}{$2-4$ months } & \multirow{3}{*}{$\begin{array}{l}\text { Project manager } \\
\text { Consultant } \\
\text { Developer } \\
\text { Users }\end{array}$} \\
\hline & $\begin{array}{l}\text { Preparation of user } \\
\text { instructions and initial } \\
\text { training of employees }\end{array}$ & $\begin{array}{l}\text { The system is ready for } \\
\text { implementation }\end{array}$ & & \\
\hline 6 & Operational testing & \begin{tabular}{|c} 
Monitoring the readiness of \\
the system for industrial \\
operation
\end{tabular} & 1 month & \\
\hline & \multicolumn{2}{|c|}{ Industrial operation } & & \multirow{3}{*}{$\begin{array}{c}\text { Project manager } \\
\text { System administrator } \\
\text { Consultant } \\
\text { Developer } \\
\text { Users }\end{array}$} \\
\hline 7 & \multicolumn{2}{|c|}{ System stabilization (working at functional comments) } & $3-6$ months & \\
\hline \multicolumn{4}{|c|}{ Support } & \\
\hline
\end{tabular}

Sources: developed by the authors

Table 4 shows that the implementation of such project lasts from 8 up to 16 months and requires the same types of human resources. Let us calculate the labour costs for this project with the implementation deadline of 1.3 years under the terms of the first project calculation (Table 5).

Thus, the implementation of the integrated project for automation requires 9860 hours. It is 1.58 times less than for the complex project with up-front modelling. However, the labour costs for the executors of the integration project make 5640 hours (57.2\%), and users -4220 hours (42.8\%). Therefore, during the integration project implementation, a structural reallocation of labour costs takes place. It occurs through 
increasing the share of time spent by project executors and reduction of the share of user costs, i.e. this project reallocates resources towards technical means of implementing and using modern digital transformation solutions that reduces the end-users participation.

Table 5. Calculation of labour costs for the development and operating of an integration project for the enterprise automation using ERP-system

\begin{tabular}{|c|c|c|c|}
\hline $\begin{array}{l}\text { Type of human } \\
\text { resources }\end{array}$ & $\begin{array}{c}\text { Participation } \\
\text { coefficient }\end{array}$ & $\begin{array}{l}\text { Stages of project } \\
\text { implementation }\end{array}$ & Calculation of labour costs \\
\hline Project monitor & 0.1 & $\begin{array}{l}\text { Stage } 1=2 \text { weeks } \\
\text { Stage } 7=6 \text { months }\end{array}$ & $(0.5+6) * 160 * 0.1=104$ hours \\
\hline Project manager & 0.2 & $\begin{array}{l}\text { Stage } 1=2 \text { weeks } \\
\text { Stage } 4=3 \text { months } \\
\text { Stage } 5=4 \text { months } \\
\text { Stage } 6=1 \text { month } \\
\text { Stage } 7=6 \text { months }\end{array}$ & $(0.5+14) * 160 * 0.2=464$ hours \\
\hline System administrator & 0.05 & $\begin{array}{l}\text { Stage } 2=2 \text { weeks } \\
\text { Stage } 7=6 \text { months }\end{array}$ & $(0.5+6) * 160 * 0.05=52$ hours \\
\hline Consultant & 1 & $\begin{array}{l}\text { Stage } 2=2 \text { weeks } \\
\text { Stage } 3=4 \text { weeks } \\
\text { Stage } 4=3 \text { months } \\
\text { Stage } 5=4 \text { months } \\
\text { Stage } 6=1 \text { month } \\
\text { Stage } 7=6 \text { months }\end{array}$ & $(1.5+14) * 160 * 1=2480$ hours \\
\hline Developer & 0.5 & $\begin{array}{l}\text { Stage } 4=3 \text { months } \\
\text { Stage } 5=4 \text { months } \\
\text { Stage } 6=1 \text { month } \\
\text { Stage } 7=6 \text { months }\end{array}$ & $14 * 160 * 0.5=1120$ hours \\
\hline Key users & 0.5 & $\begin{array}{l}\text { Stage } 2=2 \text { weeks } \\
\text { Stage } 3=4 \text { weeks } \\
\text { Stage } 4=3 \text { months }\end{array}$ & $4,5 * 160 * 0.5=360$ hours \\
\hline Users & 3 & $\begin{array}{l}\text { Stage } 5=4 \text { months } \\
\text { Stage } 6=1 \text { month } \\
\text { Stage } 7=6 \text { months }\end{array}$ & $11 * 160 * 3=5280$ hours \\
\hline \multicolumn{3}{|c|}{ Total } & 9860 hours \\
\hline
\end{tabular}

Sources: developed by the authors

The above calculations demonstrate the economic feasibility of implementing integration projects for digitalisation compared to the projects for the parallel implementation of new IT and their coordination with information systems existing at enterprises. Thus, we proved the correctness of hypothesis $\mathrm{H} 1$ and rejected hypothesis $\mathrm{H} 0$.

It should be noted that the complexity of the manufacturing relationships of industrial enterprises, industry-specific features, the scale of manufacture, the existing material and technical base as well as many other factors of the internal and external environment make it necessary to apply an individual approach to the digital transformation of enterprises. However, there are universal solutions that can be adapted to the specific features of particular business entities. One of such integrated application solutions is Business Automation Software (BAS), which has been actively implementing in Ukraine since the beginning of 2018. BAS offers three main systems for industrial enterprises, which are as follows:

1) BAS ERP, which is an innovative solution for building complex information systems for management of diversified enterprises; 
2) BAS Document management CORP, which is a modern cross-functional solution for management of business processes and collaboration of employees;

3) BAS Holding management, which is a high-tech solution for tasks automation that is relevant to a group of enterprises, i.e. a big business (BAS, 2019).

The characteristics of each component of BAS solutions is given in Table 6. In terms of digital transformation, all three solutions are interconnected by means of data exchange and seamless integration, which allows implementing these systems at enterprises with great efficiency. One of the significant advantages of BAS solutions is their module building. It provides high flexibility and adaptation of these systems to the conditions of particular manufacturing.

Table 6. Characteristics of a set of BAS solutions for an industrial enterprise

\begin{tabular}{|c|c|}
\hline BAS Solution & Characteristics \\
\hline BAS ERP & $\begin{array}{l}\text { It covers the main contours of management and accounting, that allows organising a unified } \\
\text { information system for managing various aspects of the enterprise activity, namely: } \\
\text { 1) financial management; } \\
\text { 2) budgeting; } \\
\text { 3) monitoring and analysis of the enterprise performance indicators; } \\
\text { 4) regulatory accounting; } \\
\text { 5) personnel management and payroll; } \\
\text { 6) production management; } \\
\text { 7) costs management and prime cost calculation; } \\
\text { 8) repair management; } \\
\text { 9) sales management; } \\
\text { 10) customer relationship management; } \\
\text { 11) procurement management; } \\
\text { 12) warehouse and inventory management. }\end{array}$ \\
\hline $\begin{array}{l}\text { BAS Document } \\
\text { management } \\
\text { CORP }\end{array}$ & $\begin{array}{l}\text { Altogether it solves a wide range of tasks of document accounting automation, employee } \\
\text { interaction, control and analysis of performance discipline and covers the sections as follows: } \\
\text { 1) compliance with Ukrainian legislation; } \\
\text { 2) document management; } \\
\text { 3) business processes and user work; } \\
\text { 4) project management; } \\
\text { 5) organisation of activities; } \\
\text { 6) ease of work for every day; } \\
\text { 7) search; } \\
\text { 8) accounting of working hours and control of performance; } \\
\text { 9) organisation of a distributed database; } \\
\text { 10) data exchange with other typical configurations; } \\
\text { 11) web-services for working with files. }\end{array}$ \\
\hline $\begin{array}{l}\text { BAS Holding } \\
\text { Management }\end{array}$ & $\begin{array}{l}\text { It covers the main contours of the management and fiscal accounting of the holding, namely: } \\
\text { 1) budgeting; } \\
\text { 2) investment projects; } \\
\text { 3) limitation and «payment factory»; } \\
\text { 4) centralized procurement management and contract management; } \\
\text { 5) accounting and reporting in compliance with international financial reporting standards; } \\
\text { 6) integration capabilities; } \\
\text { 7) universal processes; } \\
\text { 8) universal financial reporting; } \\
\text { 9) risk management tools; } \\
\text { 10) business analysis. }\end{array}$ \\
\hline
\end{tabular}

Sources: systematised by the authors based on (BAS, 2019) 
Therefore, each enterprise can choose only a certain list of system components to be used, and not waste time and money on other unnecessary modules. As information needs change, enterprises can change and supplement the set of «working» modules, improving the management information base. However, the disadvantage of BAS, as well as other similar systems, is that these solutions require not only a certain time for their implementation and employees training, but also significant investments. Small enterprises not always can afford it.

However, for medium and large-scale business, the implementation of information management systems is an economically viable investment. For example, thanks to the digitalisation, E.O.N. company managed to reduce specific operating costs, caused by unstable network operation, by $50 \%$ over 10 years (in Italy) and improve the quality of services by $60 \%$ (SAIDI) (in Romania). The successes have inspired the corporation for further investments in the amount of 4.7 billion euro into digitalisation of its business in 2018-2020. Duke Energy Corporation saved 31.5 million USD on repairs over three years by connecting 30,000 sensors at 50 of its power stations. Ukraine also has experience of investing in the digital transformation of enterprises. For instance, one of the largest Ukrainian energy companies, DTEK, plans to spend 350 million UAH on digitalisation of its business on 9 directions in 2019. In particular, it is planned to implement the Digital Mine project, which provides the implementation of LTE wireless communication in the underground and ground parts of mines for the exchange of data between sensors, automation devices, controllers and server equipment. This will allow not only better control of coal mining processes, but also increase in the safety level of miners and reduction of the number of accidents. The project «Digital walkdowns» consists of developing a mobile application for staff with the functionality of digital issuing of work orders, digital measurements of the main technological parameters of equipment as well as repair guidelines. In addition, it is planned to integrate these processes with the existing equipment base, its life cycle history and basic analytics, which will make it possible to use the equipment more efficiently and prevent its emergency stops (DTEK, 2019).

In general, based on the experience of world's leading corporations which implement the digitalisation projects, the main effects of these measures can be as follows (Kroll et al., 2018; Posada et al., 2015; Raymond et al., 2009; Brettel et al., 2014; Rudenko, 2018):

- reduction of the duration of products manufacturing cycles, increase in product quality while reducing manufacturing costs;

- opportunity to perform work in an aggressive work environment using robots;

- growth of opportunities for virtual modelling and simulation of manufacturing processes and situations, which causes the increase in flexibility in manufacturing;

- opportunity to collect, process and visualize information on the planning of manufacturing systems, product design and its changes during the life cycle with the corresponding changes in manufacturing systems;

- expanding opportunities for optimization of the logistics systems, products customization, instant coordination of material flows with changes in consumer demand for goods and services;

- expanding the interaction of consumers, manufacturers and suppliers at the stages of products manufacturing and consumption, which leads to the increase in efficiency of the resources use;

- increase in labour efficiency at enterprises, more rational use of working time, increased ability of the companies to launch new products to the market;

- monitoring the equipment operation, the widespread implementation of preventive maintenance, reducing equipment downtime, decreasing the loss of working time, reducing the number of accidents and their negative consequences, etc.

Achievement of the above-mentioned effects ensures the strengthening of enterprise positions in the domestic and international markets, revenue growth even in conditions of fierce competition. 
Conclusions. Overall, digital innovations in business are extremely promising in terms of reducing production costs and obtaining unique competitive advantages for business entities. It provides completely new opportunities for entrepreneurial activities by changing the requirements for the manufacturing environment, the product itself, its distribution channels, criteria for assessing the efficiency of manufacturing systems, etc. On the other hand, digitalisation processes are long-term and need constant support and improvement. In addition, they require significant expenditures of time and money, and, consequently, well-considered approaches to their investment management. Due to the current challenges of the information society that industrial enterprises face, it is advisable to implement investment projects for the digital transformation of companies based on the integration of existing enterprise information systems with modern package solutions such as BAS. At the same time, each investment project of this kind requires a thorough economic justification in order to form adequate mechanisms for transformation management to enhance their positive effects and reduce negative consequences. The development of these mechanisms is the subject of further research in this direction.

Author Contributions: conceptualization, I. S. and K. Z.; methodology, I. S. and V. K.; software, K. Z.; validation, formal analysis, investigation, resources, data curation, writing-original draft preparation, I. S. and K.Z.; writing-review and editing, I.S. and H. R.; visualization, K.Z.; supervision, project administration, funding acquisition, I. S, V. K and O. S.

Funding: This article is prepared as a part of the research projects «Modelling the transfer of ecoinnovations in the enterprise-region-state system: impact on Ukraine's economic growth and security» (№ 0119U100364) and «Development of fundamental principles of reproduction mechanism of the social and economic development during the Third industrial revolution» (№ 0118U003578) financed by the state budget of Ukraine.

\section{References}

Apal'kova, V. V. (2015). Concept of the digital economy development in the European Union and prospects for Ukraine. Bulletin of Dnipropetrovsk University. Series «Innovation Management», 4, 9-18.

BAS (2019). BAS solutions. Retrieved from: https://www.bas-soft.eul.

Bilan, Y., Streimikiene, D., Vasylieva, T., Lyulyov, O., Pimonenko, T., \& Pavlyk, A. (2019). Linking between renewable energy, $\mathrm{CO}_{2}$ emissions, and economic growth: Challenges for candidates and potential candidates for the EU membership. Sustainability,11(6), 1528. [Google Scholar] [CrossRef]

Blix, M. (2015). The economy and digitalisation - opportunities and challenges. Retrieved from: https:/www.ifn.se/storage/ma/1c77ce47b5384acdadf960ef0c26cdeb/20032095be784cdda28aac8c6b7b25c8/pdf/6F21662B08AFB 948E3D053DD9EAC209BC73A19B1/blix digitalisation report 20151215.pdf

Brettel, M., Friederichsen, N., Keller, M., \& Rosenberg, M. (2014). How virtualization, decentralization and network building change the manufacturing landscape. An Industry 4.0 Perspective. International journal of mechanical, industrial science and engineering, 8 (1), 37-44. [Google Scholar] [CrossRef]

Deutsche Welle (2019). Again Made in Germany: industrial production returns to Germany. Retrieved from: https://www.dw.com/rul

DTEK (2019). DTEK will spend UAH 350 million on digital transformation. Where will the money go? Retrieved from: https://ain.ua/2019/04/23/dtek-potratit-na-cifrovuyu-transformaciyu-350-mln-grn-na-chto-pojdut-dengi/

Gartner (2019). IT Glossary. Retrieved from: https://www.gartner.com/it-glossary/

Sotnyk I. M., \& Goncharenko O. S. (2015). Formation of ecology and economic mechanism of dematerialization at the enterprise. Marketing and innovation management, 2, 258-266. [Google Scholar]

Gupta, Ch. (2018). What does IloT mean for MES? Automation World, 8.01. Retrieved from: https://www.automationworld.com/what-does-iiot-mean-mes

Hewlett Packard Enterprise (2019). What is digital transformation? Retrieved from: https://www.hpe.com/us/en/what-is/digitaltransformation.html

Hounshell, L. (2018). The Industrial Internet of Things, digitalisation and the future of business. Retrieved from: https://www.forbes.com/sites/forbestechcouncil/2018/07/30/the-industrial-internet-of-things-digitalisation-and-the-future-ofbusiness/. 
Ibragimov, Z., Lyeonov, S., \& Pimonenko, T. (2019). Green investing for SDGS: EU experience for developing countries. Economic and Social Development: Book of Proceedings, 867-876. [Google Scholar]

Ibragimov, Z., Vasylieva, T., \& Lyulyov, O. (2019a). The national economy competitiveness: effect of macroeconomic stability, renewable energy on economic growth. Economic and Social Development: Book of Proceedings, 877-886. [Google Scholar]

IT-Enterprise (2019). Retrieved from: https://www.it.ua/knowledge-base/technology-innovation/.

Karcheva, G. T., Ogorodnya, D. V., \& Open'ka, V. A. (2017). The digital economy and its impact on the development of national and international economics. Finansovyy prostir, 3, 13-21.

Kolyadenko, S. V. (2016). Digital economy: preconditions and stages of formation in Ukraine and in the world. Ekonomika. Finansy. Menedzhment: aktyalni pytannia nauky I praktyky, 6, 105-112.

Kraus, N. M., Goloborod'ko, O. P., \& Kraus, K. M. (2018). Digital economy: trends and prospects for the avant-garde nature of development. Efektyvna ekonomika, 1. Retrieved from: http://www.economy.nayka.com.ua/pdf/1_2018/8.pdf

Kroll, H., Horvat, D., \& Jager, A. (2018). Effects of automatisation and digitalisation on manufacturing companies' production efficiency and innovation performance (No. 58). Fraunhofer ISI Discussion Papers - Innovation Systems and Policy Analysis. [Google Scholar]

Lavi, Y. (2017). Industry 4.0: Harnessing the power of ERP and MES integration Industry Week, 20.07. Retrieved from: https://www.industryweek.com/supply-chain-technology/industry-40-harnessing-power-erp-and-mes-integration.

Melnyk, L. H., Dehtiarova, I. B., Horobchenko, D. V. \& Matsenko, O. M. (2017). Innovations in the context of modern economic transformation processes of enterprise, region, country: the EU experience. Marketing and management of Innovations, (4), 260271. [Google Scholar] [CrossRef]

Hakobyan, N., Khachatryan, A., Vardanyan, N., Chortok, Y., \& Starchenko, L. (2019). The implementation of Corporate Social and Environmental Responsibility practices into competitive strategy of the company. Marketing and Management of Innovations, 2 , 42-51. [CrossRef]

Panorama Consulting Solutions (2016). Business intelligence: the missing link to your ERP strategy? Retrieved from: https://www.panorama-consulting.com/business-intelligence-the-missing-link-to-your-erp-strategyl

Posada, J., Toro, C., Barandiaran, I., Oyarzun, D., Stricker, D., de Amicis, R., \& Vallarino, I. (2015). Visual computing as a key enabling technology for Industry 4.0 and industrial internet. IEEE computer graphics and applications, 35 (2), 26-40. [Google Scholar] [CrossRef]

Prokopenko, O. V., Biloshkurska, N. V., Biloshkurskyi, M. V., \& Omelyanenko, V. A. (2019). The role of banks in national innovation system: general strategical analytics. Financial and credit activity: problems of theory and practice, 3(30), 26-35. [Google Scholar] [CrossRef]

Raymond, L., Croteau, A. M., \& Bergeron, F. (2009, May). The integrative role of IT in product and process innovation: growth and productivity outcomes for manufacturing. In International Conference on Enterprise Information Systems. (pp. 27-39). Springer, Berlin, Heidelberg. [Google Scholar] [CrossRef]

Rubanov, P., Vasylieva, T., Lyeonov, S., \& Pokhylko, S. (2019). Cluster analysis of development of alternative finance models depending on the regional affiliation of countries. Business and Economic Horizons (BEH), 15(1232-2019-892), 90-106. [Google Scholar]

Rudenko, M. V. (2018). Digitalisation of economy: new opportunities and perspectives. Economy and state, 11. Retrieved from: http://www.economy.in.ua/pdf/11_2018/13.pdf. [CrossRef]

Samuels, M. (2018). What is a chief digital officer? Everything you need to know about the CDO explained. Retrieved from: https://www.zdnet.com/article/what-is-a-chief-digital-officer-everything-you-need-to-know-about-the-cdo/

Schwab, K. (2016). The Fourth Industrial Revolution: what it means, how to respond. World Economic Forum. Retrieved from https://www.weforum.org/agenda/2016/01/the-fourth-industrial-revolution-what-it-means-and-how-to-respond/

Sotnyk, I.M., Volk, O.M., \& Chortok Yu.V. (2013). Increase of ecological-economic efficiency of ICT as a resource saving innovative direction. Actual Problems of Economics, 9, 229-235.

Theory of Constraints (2019). Lean Production. Retrieved from: https:/www.leanproduction.com/theory-of-constraints.html

Tokmakova, I. V., Shatokhina, D. A., \& Melnik, S. V. (2018). Strategic management of the enterprises' development in the conditions of economy's digitalisation. Bulletin of the Economy of Transport and Industry, 64, 283-291.

Veretyuk, S. M., \& Pilinsky, V. V. (2016). Determination of the priority directions for digital economy's development in Ukraine. Scientific notes of the Ukrainian Research Institute of Communication, 2, 51-58.

Zielinski, M. (2019). Digitalise or cease to exist. Economic truth. Retrieved from: https://www.epravda.com.ua/columns/2019/01/11/644176/ 
Ірина Сотник, доктор економічних наук, професор, Сумський державний університет (Україна);

Костянтин Завражний, Сумський державний університет (Україна);

Володимир Касьяненко, доктор економічних наук, Сумський державний університет (Україна);

Хунек Рубік, Ph.D., Чеський університет наук про життя Прага (Чехія);

Олександр Сідоров, INGENUM (Іспанія)

Інвестиційний менеджмент цифрових інновацій бізнесу

У статті розглядаються питання інвестиційного менеджменту цифрових інновацій сучасного бізнесу. Основною метою дослідження $є$ розроблення підходів до інвестиційного менеджменту інноваційних процесів цифровізації компаній та обгрунтування економічної ефективності інвестиційних проектів з використання інноваційних інформаційних технологій у контексті їх взаємозв'язку з існуючими інформаційними рішеннями управління підприємствами. Актуальність дослідження полягає у необхідності зміни методів ведення й управління сучасним бізнесом з урахуванням досягнень Третьої та Четвертої промислових революцій, які формують інноваційну бізнес-філософфію, засновану на інформатизації та цифровізації процесів виробництва і постачання продукції. Імплементація інноваційних цифрових технологій у бізнес-процеси вимагає значних витрат, що актуалізує питання ї мінімізації. Систематизація літературних джерел та підходів до інвестиційного менеджменту промислової цифровізації виявила відсутність комплексних рішень цієї проблеми. У зв'язку з цим, на основі порівняльного аналізу авторами виявлено особливості розвитку бізнесу в умовах Четвертої промислової революції й обгрунтовано необхідність інтеграції сучасних інформаційних систем управління діяльністю підприємств на платформі цифровізації бізнеспроцесів. 3 метою створення карти цифрових інновацій бізнесу запропоновано застосовувати теорію обмежень системи, що дозволяє визначити, з якої з функціонуючих інформаційних систем підприємства (бізнес-аналітика, Business intelligence - Bl; система планування ресурсів підприємства, Enterprise Resource Planning - ERP; система управління виробничими процесами, Manufacturing Execution System - MES; Промисловий Iнтернет речей, Industrial Internet of Things - IIoT) варто розпочати цифрову трансформацію. На підставі використання структурного підходу у статті сформовано етапи розроблення проекту цифрової трансформації компанії. Економічне обгрунтування вибору таких альтернативних проектів виконано на основі оцінки трудових витрат на реалізацію двох варіантів цифрової інновації суб'єкта господарювання: комплексного проекту автоматизації з попереднім моделюванням та інтеграційного проекту автоматизації з поступовим впровадженням нової інформаційної системи. Результати оцінки засвідчили економічні переваги імплементації інтеграційного проекту, що забезпечує в 1,58 рази менше трудовитрат і може бути реалізований із використанням універсальних пакетних рішень типу Business Automaton Software (BAS). Аналіз результатів впроваджених і потенціалу запланованих проектів цифровізаціі бізнесу в Україні та світі дозволив узагальнити ефекти від їх імплементації і підтвердив необхідність подальшого розвитку механізмів інвестиційного менеджменту цифрових інновацій у компаніях.

Ключові слова: автоматизація, бізнес, екологізація, ефективність, інвестиційний менеджмент, інновація, інформаційні технології, проект, цифровізація, ERP.

Manuscript received: 30.09.2019.

(C) The authors 2020. This article is published with open access at Sumy State University. 